\title{
THE PRESCRIBING OF DRUGS USED IN THE TREATMENT OF DIABETES
}

\author{
O. L. WADE, D. R. HADDEN, AND H. HOOD \\ Department of Clinical Pharmacology, University of Birmingham, Royal Victoria Hospital, Belfast, and Department of \\ Therapeutics and Pharmacology, The Queen's University, Belfast
}

The methods of disciplining the prescription data available in Northern Ireland were described by Wade and Hood (1972) and have been applied to the prescribing of antidiabetic drugs. Prescribing of insulin and oral hypoglycaemic agents was examined separately over the three-month period April to June 1966. In order to facilitate comparison of quantities of the different preparations used an 'equivalent dose' was defined (Table I).

TABLE I

ANTIDIABETIC PREPARATIONS INCLUDED IN SURVEY AND THEIR CONVERSION TO 'EOUIVALENT DOSES' OF APPROXIMATELY ONE DAY'S REQUIREMENTS

\begin{tabular}{|c|c|c|}
\hline Preparation & & One 'Equivalent Dose' \\
\hline $\begin{array}{l}\text { Insulin } \ldots \\
\text { Metformin (Glucophage) } \ldots \\
\text { Phenformin (Dibotin, DBI) } \ldots \\
\text { Tolbutamide (Rastinon, Orinase) } \\
\text { Chlorpropamide (Diabinese) }\end{array}$ & \begin{tabular}{l|}
$\cdots$ \\
$\cdots$ \\
$\cdots$ \\
$\cdots$
\end{tabular} & $\begin{array}{l}40 \text { units } \\
2 \mathrm{~g} \\
50 \mathrm{mg} \\
1 \mathrm{~g} \\
250 \mathrm{mg}\end{array}$ \\
\hline
\end{tabular}

In general, antidiabetic therapy is controlled by a hospital consultant who advises the general practitioner which drug to prescribe. Relatively little independent prescribing by general practitioners occurs, in comparison with other parts of the world, due to the development over the past 20 years of well-organized, hospital-based diabetic clinics. Repeat prescriptions are written as required by the general practitioners and there is no prescribing of drugs to outpatients in hospitals in Northern Ireland.

In Northern Ireland during the survey period an average of 3,400 prescriptions were written per month for antidiabetic preparations: $40 \%$ of these were for insulin injections and $60 \%$ were for oral agents. During the three months almost threequarters of a million 'equivalent doses' of antidiabetic therapy were prescribed, a rate of almost 6 'equivalent doses' per thousand of the population per day. This prescribing rate would suggest that the prevalence of diabetes requiring insulin or oral hypoglycaemic treatment in Northern Ireland is of the order of $0.6 \%$, which is similar to the estimate of Malins (1968) for the prevalence of known diabetes in the general population $(0.64 \%)$.

\section{PresCribing OF INSULIN}

The 743 general practitioners in Northern Ireland wrote an average of 1,343 prescriptions for insulin per month. Over $60 \%$ of these prescriptions were for the $10 \mathrm{ml}$ vial containing 40 units per $\mathrm{ml}$. An average of 3 'equivalent doses' of insulin (120 units of insulin) were prescribed per thousand population per day over the three-month period. Prescribing in each of the six individual counties of Northert Ireland was fairly close to this average, the greates deviations being in counties Antrim and London= derry where it was $28 \%$ and $20 \%$ respectively above average and in the city of Belfast where it was $26 \%$ below average (Table II). Figure 1, a detailed map of the distribution of insulin prescribing in 65 areas of Northern Ireland, shows a fairly even spread of use except in Co. Fermanagh, the most rural area in the south-west, where insulin prescribing, in common with all prescribing, was low, although even here there were considerable local variations.

\section{Prescribing of Oral Hypoglycaemics}

An average of 2,055 prescriptions were written for hypoglycaemic tablets per month; $54 \%$ of these were for the two strengths of chlorpropamide (prescribed by over $60 \%$ of general practitioners in Northern Ireland); $33 \%$ were for tolbutamide (prescribed by $44 \%$ of general practitioners); and $11 \%$ were for metformin (prescribed by $20 \%$ of general practitioners).

An average of 2.7 'equivalent doses' of hypoglycaemic tablets were prescribed per thousand of the population per day during the three-month period in 1966 but there were considerable deviations from the average in counties Down and Armagh where prescribing was $36 \%$ and $30 \%$ respectively above average and in Co. Fermanagh where 
TABLE II

DISTRIBUTION OF PRESCRIBING OF INSULIN AND ORAL HYPOGLYCAEMICS AND OF POPULATION IN COUNTIES OF NORTHERN IRELAND DURING A THREE-MONTH PERIOD IN 1966

\begin{tabular}{|c|c|c|c|c|c|c|c|c|}
\hline & & & \multicolumn{2}{|c|}{ Population* } & \multicolumn{2}{|c|}{ Insulin } & \multicolumn{2}{|c|}{ Tablets } \\
\hline & & & Number & Percent & $\begin{array}{c}\text { 'Equivalent } \\
\text { Doses' }\end{array}$ & $\begin{array}{c}\text { 'Equivalent } \\
\text { Doses'/1,000 } \\
\text { per Day }\end{array}$ & $\begin{array}{c}\text { 'Equivalent } \\
\text { Doses' }\end{array}$ & $\begin{array}{c}\text { 'Equivalent } \\
\text { Doses'/1,000 } \\
\text { per Day }\end{array}$ \\
\hline $\begin{array}{l}\text { Belfast .. } \\
\text { Co. Antrim } \\
\text { Co. Armagh } \\
\text { Co. Down } \\
\text { Co. Fermanagh } \\
\text { Co. Londonderry } \\
\text { Co. Tyrone }\end{array}$ & $\begin{array}{l}\cdots \\
\cdots \\
\cdots \\
\cdots \\
\cdots\end{array}$ & \begin{tabular}{l|}
$\ldots$ \\
$\ldots$ \\
$\cdots$ \\
$\cdots$ \\
$\cdots$ \\
$\cdots$
\end{tabular} & $\begin{array}{r}513,958 \\
238,849 \\
107,663 \\
223,870 \\
38,397 \\
168,566 \\
135,847\end{array}$ & $\begin{array}{l}36 \% \\
17 \% \\
7 \% \\
16 \% \\
3 \% \\
12 \% \\
9 \%\end{array}$ & $\begin{array}{r}102,605 \\
82,065 \\
31,035 \\
64,762 \\
9,775 \\
54,710 \\
39,315\end{array}$ & $\begin{array}{l}2 \cdot 2 \\
3 \cdot 8 \\
3 \cdot 2 \\
3 \cdot 2 \\
2 \cdot 2 \\
3 \cdot 6 \\
3 \cdot 2\end{array}$ & $\begin{array}{r}126,667 \\
57,613 \\
34,646 \\
74,657 \\
4,859 \\
29,610 \\
21,820\end{array}$ & $\begin{array}{l}2 \cdot 7 \\
2 \cdot 7 \\
3 \cdot 6 \\
3 \cdot 7 \\
1 \cdot 4 \\
1 \cdot 9 \\
1 \cdot 8\end{array}$ \\
\hline Whole Province . & .. & $\ldots$ & $1,427,150$ & $100 \%$ & 384,267 & $3 \cdot 0$ & 349,872 & $2 \cdot 7$ \\
\hline
\end{tabular}

* Northern Ireland Registrar General (1968)

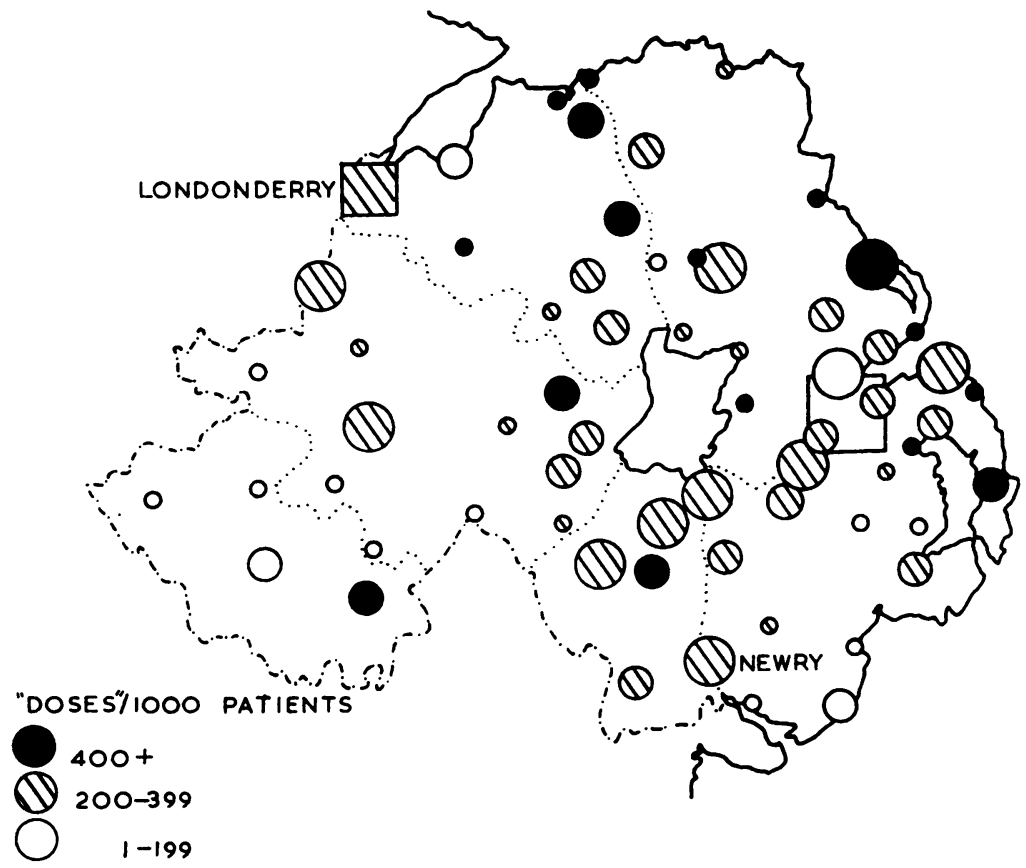

FIG. 1. Geographical distribution of prescribing of insulin in

Northern Ireland, April to June 1966 (Cities of Belfast and London-

derry are represented by squares and the remaining towns by circles

whose size is proportional to the population).

prescribing was $48 \%$ below average (Table II). Figure 2, a detailed map of tablet prescribing, shows a distinct pattern of prescribing-high use in the south-east, moderate use in the north-east and central area, and low use in the west-which is more closely related to broad county areas than, as might have been expected, to smaller areas centred on regional diabetic clinics indicated by crosses on the map. Preference for individual preparations also showed a pattern closer to the county distribution than to the areas of the regional clinics. For example, tolbutamide was prescribed at least once by more than $80 \%$ of the general practitioners in 13 of the 17 towns in Co. Antrim but was never used by more than $75 \%$ of general practitioners in any of the 18 towns in Co. Down, while chlorpropamide was used by more than $80 \%$ of the general practitioners in 14 towns in Co. Down but in only five towns in Co. Antrim. Since 1966 there has been a general trend towards increased prescribing of all oral agents except tolbutamide, the 


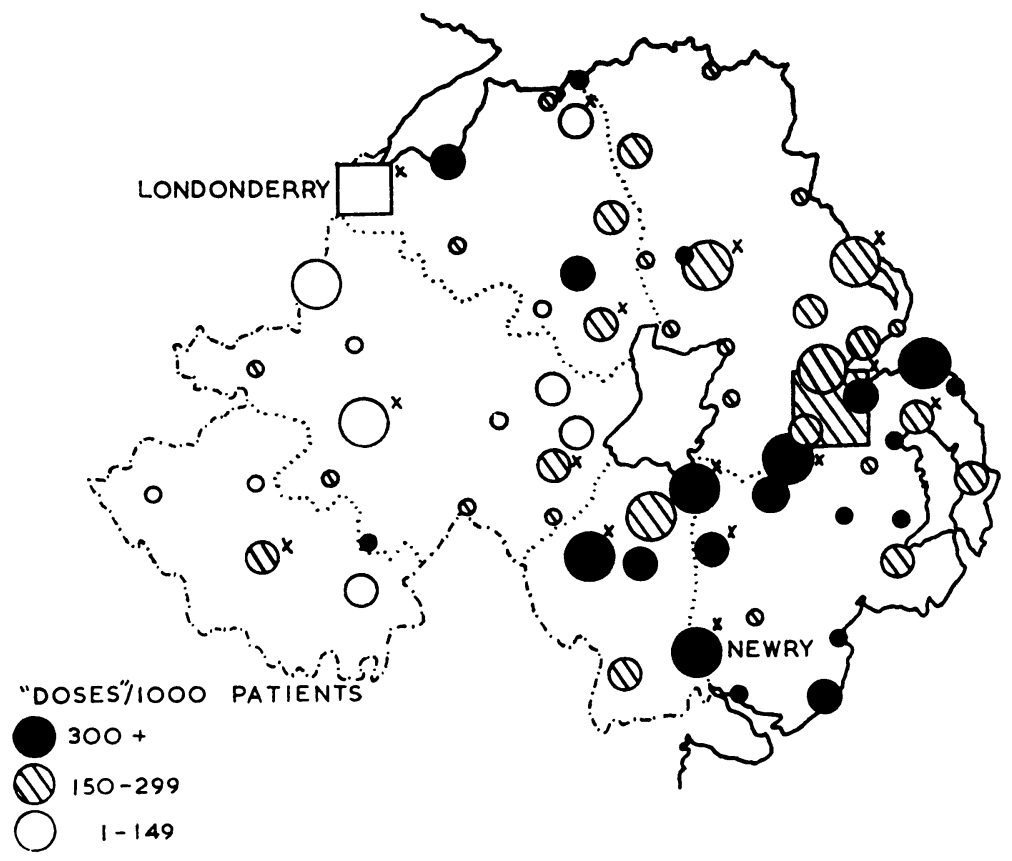

FIG. 2. Geographical distribution of prescribing of oral hypoglycaemics in Northern Ireland, April to June 1966 (crosses indicate towns in which diabetic clinics are situated).

TABLE III

NUMBER OF PRESCRIPTIONS (AVERAGE NUMBER OF TABLETS PER PRESCRIPTION) FOR ORAL HYPOGLYCAEMIC TABLETS IN APRIL 1966-71, NORTHERN IRELAND

\begin{tabular}{|c|c|c|c|c|c|c|}
\hline Preparation & 1966 & 1967 & 1968 & 1969 & 1970 & 1971 \\
\hline $\begin{array}{ll}\text { Chlorpropamide } \\
\text { Tolbutamide } \\
\text { Metformin } \\
\text { Phenformin } \\
\text { Others }\end{array}$ & $\begin{array}{c}1,029 \\
(90)^{*} \\
660 \\
(109) \\
200 \\
(104) \\
46 \\
(94) \\
0\end{array}$ & $\begin{array}{l}1,202 \\
(91) \\
644 \\
(117) \\
271 \\
(110) \\
61 \\
(103) \\
0\end{array}$ & $\begin{array}{l}1,296 \\
(92) \\
664 \\
(114) \\
309 \\
(108) \\
111 \\
(86) \\
72\end{array}$ & $\begin{array}{c}1,318 \\
(98) \\
620 \\
(128) \\
345 \\
(114) \\
180 \\
(94) \\
71\end{array}$ & $\begin{array}{l}1,299 \\
(97) \\
644 \\
(127) \\
335 \\
(129) \\
215 \\
(97) \\
60\end{array}$ & $\begin{array}{l}1,211 \\
(99) \\
577 \\
(127) \\
423 \\
(130) \\
213 \\
(101) \\
150\end{array}$ \\
\hline Total & $\begin{array}{c}1,935 \\
(98)\end{array}$ & $\begin{array}{l}2,238 \\
(102)\end{array}$ & $\begin{array}{l}2,452 \\
(100)\end{array}$ & $\begin{array}{l}2,534 \\
\text { (107) }\end{array}$ & $\begin{array}{l}2,553 \\
(109)\end{array}$ & $\begin{array}{l}2,574 \\
(110)\end{array}$ \\
\hline
\end{tabular}

*Average number of tablets per prescription in parentheses.

use of which has decreased slightly (Table III). The increase was most marked in the prescribing of phenformin.

\section{COMPaRison OF THE USE OF ORAL HyPOGLYCAEMIC} THERAPY IN LONDONDERRY AND NEWRY

After Belfast, which contains approximately onethird of the Northern Ireland population, Londonderry is the next largest urban centre of population and Newry the fifth largest with a population nearly half that of Londonderry. In both places the use of insulin was similar and not very different from the provincial mean. But for oral antidiabetic drugs Londonderry was a low prescribing area (132 'equivalent doses'/1,000 population/3 months, i.e. 1.46 per day) and Newry was a high prescribing area (411 'equivalent doses' $/ 1,000$ population $/ 3$ months, i.e. $4 \cdot 52$ per day). A further investigation was made into the diabetic populations of the two cities to study this difference in prescribing habits in April to June 1966.

With the assistance of the Northern Ireland General Health Services Board's pricing bureau computer facilities, the prescription scripts were traced for patients of the doctors practising in the two towns who had been prescribed hypoglycaemic tablets during the survey period in 1966. The results are summarized in Table IV. The traced prescriptions showed that virtually the same proportion of the total population of the two towns was receiving oral therapy for diabetes and the sex-age composition of the two groups of patients was similar. The greater prescribing of oral antidiabetic drugs in Newry was because the patients were prescribed the oral drugs in much larger daily doses than were patients in Londonderry. 
TABLE IV

DEIAILS OF DIABETIC PATIENTS IN LONDONDERRY AND NEWRY OBTAINED FROM PRESCRIPTION SCRIPTS FOR A THREE-MONTH PERIOD IN 1966

\begin{tabular}{|c|c|c|}
\hline & Londonderry & Newry \\
\hline $\begin{array}{l}\text { Total number of persons on } \\
\text { doctors' lists }\end{array}$ & 75,707 & 30,599 \\
\hline $\begin{array}{l}\text { 'Equivalent Doses’ of oral } \\
\text { hypoglycaemics prescribed } \\
1,000 \text { population } \quad . .\end{array}$ & 132 & 411 \\
\hline $\begin{array}{l}\text { Patients whose prescriptions } \\
\text { for oral hypoglycaemics were } \\
\text { located } \\
\text { loceres }\end{array}$ & $\left.\begin{array}{ll}\mathbf{M} & 34 \\
\mathbf{F} & 67\end{array}\right\} \quad 101$ & $\left.\begin{array}{ll}\mathbf{M} & 12 \\
\mathbf{F} & 25\end{array}\right\} \quad 37$ \\
\hline $\begin{array}{l}\text { Patients receiving oral hypo- } \\
\text { glycaemic therapy / } 1,000 \\
\text { population }\end{array}$ & $1 \cdot 33$ & $1 \cdot 21$ \\
\hline Average age (years) $\quad$.. & 62 & 63 \\
\hline
\end{tabular}

The consultant physicians at the diabetic clinics in the two towns were visited and asked if they could suggest reasons for the wide variations in use of antidiabetic tablets in their areas. The most important fact which came to light was that the physician in Londonderry was able to call on the services of a trained dietician, whereas the physician in Newry was not. It seemed probable that control of blood sugar was being achieved in Newry by larger doses of oral hypoglycaemic tablets and less adequate dietary supervision than in Londonderry.

\section{Follow-up of Patients treated at THE Two FLINICS}

A year later, in 1967, a further investigation was carried out over a two-month period of all patients who attended the diabetic clinics at Newry and Londonderry. This was carried out with the limited intention of determining whether antidiabetic drugs were being prescribed to different types of diabetics in the two areas, and the age, weight, and drugs recommended for each patient were recorded. It was found that the patients for whom oral antidiabetic therapy was recommended were of the
TABLE V

DETAILS OF DIABETIC PATIENTS IN LONDONDERRY AND NEWRY AREAS ATTENDING DIABETIC CLINICS IN A TWO-MONTH PERIOD IN 1967

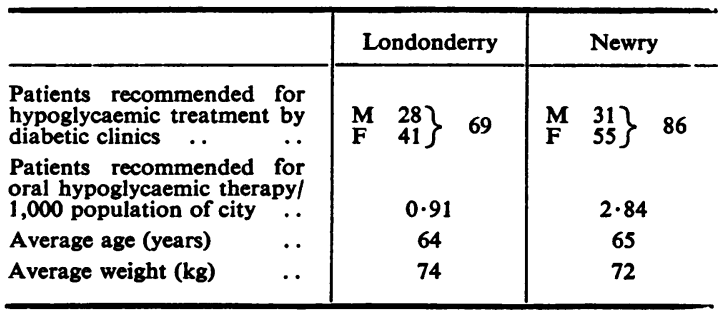

same age and weight in the two centres (Table V). Because patients came to the clinics from many towns and villages outside the two cities the populations from which they were drawn was not known, but in relation to the size of the two centres there was in 1967 a strong suggestion that oral hypoglycaemics were being used more frequently as well as in bigger doses in Newry than at Londonderry.

In 1970, three years later, a review was made of the records of all the patients for whom data had been obtained in 1967. It was found (Table VI, Figure 3) that $15 \%$ of the patients in Londonderry and $27 \%$ of those in Newry had died. Analysis of these figures shows a standardized death rate of 174 per 1,000 patients in Londonderry and 265 in Newry which, although suggestive, is not statistically significant. Although no definite conclusions can be drawn from these figures, the application of this method of making a 'therapeutic audit' of the effectiveness of treatment might well be very revealing if done as a prospective study on a larges population and would allow comparison with studies in other countries (Universities Group Diabetic Program, 1970a b). Similar studies of prescribing might also be of value in assessing the effectiveness of therapy of other diseases besides diabetes.

TABLE VI

PATIENTS ATTENDING DIABETIC CLINICS IN LONDONDERRY AND NEWRY AREAS DURING A TWO-MONTH PERIOD IN 1967 SHOWING, BY AGES, HOW MANY HAD DIED THREE YEARS LATER

\begin{tabular}{|c|c|c|c|c|c|c|c|c|c|}
\hline \multirow[b]{2}{*}{ Town } & & & \multicolumn{6}{|c|}{ Age of Clinic Patients (years) } & \multirow{2}{*}{$\begin{array}{c}\text { Total No. o } \\
\text { Patients }\end{array}$} \\
\hline & & & $<40$ & $40-49$ & $50-59$ & $60-69$ & $70-79$ & $80+$ & \\
\hline \multirow[b]{2}{*}{ Londonderry } & & 1967 sample & & 3 & 17 & 31 & 14 & 4 & 69 \\
\hline & .. & $\begin{array}{l}\text { No. alive in } 1970 \\
\text { No. dead by } 1970 \\
\text { Untraced }\end{array}$ & & 3 & $\begin{array}{r}16 \\
1\end{array}$ & $\begin{array}{r}27 \\
4\end{array}$ & $\begin{array}{l}8 \\
4 \\
2\end{array}$ & $\begin{array}{l}2 \\
1 \\
1\end{array}$ & $\begin{array}{r}56 \\
10 \\
3\end{array}$ \\
\hline \multirow[b]{2}{*}{ Newry } & & 1967 sample & 3 & 4 & 14 & 29 & 32 & 4 & 86 \\
\hline & $\cdots$ & $\begin{array}{l}\text { No. alive in } 1970 \\
\text { No. dead by } 1970 \\
\text { Untraced }\end{array}$ & 3 & $\begin{array}{l}3 \\
1\end{array}$ & $\begin{array}{l}9 \\
4 \\
1\end{array}$ & $\begin{array}{r}25 \\
4\end{array}$ & $\begin{array}{r}20 \\
11 \\
1\end{array}$ & $\begin{array}{l}1 \\
3\end{array}$ & $\begin{array}{r}61 \\
23 \\
2\end{array}$ \\
\hline
\end{tabular}



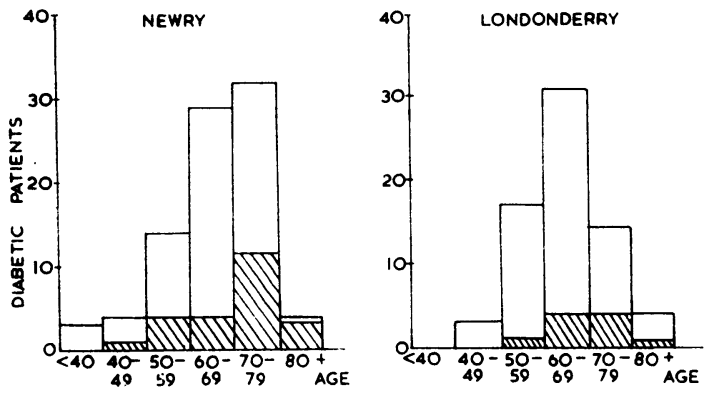

Fic. 3. Ages of patients attending diabetic clinies in Londonderty and Newry in 1967 showing those known to have died (shaded) between then and 1970 .

\section{SUMMARY}

A survey of drugs used in the treatment of diabetes by general practitioners in Northern Ireland is reported.

The use of insulin per 1,000 patients on a doctor's list is remarkably uniform throughout the practices. The use of oral hypoglycaemic drugs varies greatly and the reasons for the great difference found in two towns, Newry and Londonderry has been investigated.
We are very grateful to Dr. R. G. Vine, M.D., F.R.C.P. and Dr. E. L. Wilson, M.D., M.R.C.P.I. for assistance with information about diabetic patients under their $\bar{D}$ care in Londonderry and Newry.

We wish to acknowledge a grant in support of this work from the Nuffield Provincial Hospitals Trust, and to thank the Officers of the Northern Ireland General Health Services Board and the Government Computer Services for their generous and unstinted help over many years. We are especially indebted to Dr. G. D. Stewart, Dr. R. P. Maybin, and Mr. A. W. Kernohan; without their help these studies would have been impossible.

\section{REFERENCES}

Malins, J. M. (1968). Clinical Diabetes Mellitus. Eyre \& Spottiswoode, London.

NORTHERN IRELAND Registrar General (1968) Census $\stackrel{\rho}{\vec{\gamma}}$ of Population, 1966. General Report. H.M.S.O., ㄱ Belfast.

University Group Diabetes Program (1970a). A study $\stackrel{\vec{A}}{\vec{A}}$ of the effects of hypnglycaemic agents on vascular 0 complications in patients with adult-onset diabetes. $I$. Design, methods and baseline results. Diabetes, 19 , Suppl. 2, p. 747.

(1970b). A study of the effect of hypoglycaemic agents on vascular complications in patients with adult-onset diabetes. II. Mortality results. Diabetes 19, Suppl. 2, p. 789.

WADE, O. L., and HooD, H. E. (1972). An analysis 过 prescribing of an hypnotic in the community. Brit. prev. soc. Med., 26, 121. 